\title{
Morphology and Molecular Biology of Benthic Java Sea Shark Ray Rhina ancylostoma Bloch and Scheider 1801 (Elasmobranchia: Rhinidae)
}

\author{
Agus Hartoko $^{1^{*}}$, Delianis Pringgenies ${ }^{2}$, Amelia Cahya Anggelina $^{2}$ \\ and Takashi Matsuishi ${ }^{3}$ \\ ${ }^{1}$ Department of Fisheries, Faculty of Fisheries and Marine Science, Diponegoro University, \\ Semarang, Indonesia. \\ ${ }^{2}$ Department of Marine Science, Faculty of Fisheries and Marine Science, Diponegoro University, \\ Jalan Prof. Sudarto, SH Kampus Undip Tembalang, Semarang, Indonesia. \\ ${ }^{3}$ Department of Fisheries Science, Hokkaido University, Japan.
}

\begin{abstract}
Authors' contributions
The work had been carried out in collaboration among all authors responsibility. Author $A H$ as the first author is research coordinator, main concept and manuscript finalization. Author DP as second author contribute for DNA analysis and discussion. Author ACA contribute for laboratory analysis.

All authors read and approve the final manuscript.
\end{abstract}

Article Information

DOI: $10.9734 / A R R B / 2020 / v 35 i 430208$

Editor(s):

(1) Paola Angelini, University of Perugia, Italy.

(2) Dr. Manikant Tripathi, Dr. Ram Manohar Lohia Avadh University, India.

Reviewers:

(1) B. Gunalan, Thiru Kolanjiappar Government Arts College, India.

(2) Adeyeye, Samuel Ayofemi Olalekan, Ton Duc Thang University, Vietnam. Complete Peer review History: http://www.sdiarticle4.com/review-history/57207

Original Research Article

Received 10 March 2020

Accepted 17 May 2020

Published 23 May 2020

\section{ABSTRACT}

Aims: Morphology and molecular biology of a rare shark-rays Rhina ancylostoma caught from Java sea.Indonesia.

Study Design: Morphology, morphometry and DNA analysis of the fish specimen.

Place and Duration of Study: Sample wascollected from fish auction hall at north Java, specimen now stored in Lab of Ichtiology. Department of Fisheries. Faculty of Fisheries and Marine Science. Diponegoro University, between March to December 2019.

Methodology: DNA extraction, amplification and molecular identification of fish sample.Yield of DNA supernatant transferred in an eppendeorf tube and stored in $4^{\circ} \mathrm{C}$ for further process. PCR 
amplification. Part of Mithocondrial DNA COI (Cytochrome Oxidase subunit-I) gen was amplified using Polymerase Chain Reaction (PCR) method. Then matched up with GenBank database at $\mathrm{NCBI}$ using Basic Local Alignment Search Tool (BLAST) analysis. Philogenetic tree was set using Neighbor-Joining method, Kimura-2 parameter model and 1,000 bootstrap replication. Some sequence from NCBI GenBank were inputted into philogenetic tree as comparison.

Results: Rhina ancylostoma as one of demersal shark rays catch from tropical shallow Java sea. Range of Total Length $73-200 \mathrm{~cm}$ and dominant Total Length catch $125 \mathrm{~cm}$. Morphologyis characterised with three lines of spine thorn on the head, morphometry characteriswide of head to TL ratio 0.77. DNA analysis had confirmed the specimen of $\mathrm{AH} 2$ as Rhina ancylostoma based on homological match up of sequence of Gen Bank database with reference accesion number KU721837.1 with length sequence of 665 bpand identical similarity of $99.84 \%$ for specimen Accession number LC 505461.

Conclusion: Rhina ancylostoma as one of demersal shark rays catch from Java sea. Range Total Length $(T L)$ of catch $73-200 \mathrm{~cm}$ and dominant TL catch range $101-125 \mathrm{~cm}$. Morphologically character of wide head ratio with three lines of spine thorn on the head. Nearest genetic distance of 0.02 to Rhincobatushorkelii and 0.017 to $R$. australiae. Longest genetic distance of 0.243 to Potamotrygon motoro.

Keywords: Morphology; molecular biology; shark-ray; Java-sea; Rhinidae.

\section{INTRODUCTION}

High biodiversity of tropical seawater teleost and elasmobranch of Indonesia is very well known. High biodiversity and high consumption of the fish isneed to be carefully managed for sustainable fish resource use [1]. Consumption need in nowadays demand for the elasmobrach fish was even higher thanlast decades demands. Specifically for elasmobranch sharks market demand as high price commodity is mainly for the sharkfins for Asean demand market [2]. These highdemand had driven vastly for fisherman to catch more sharks and mainly for its fin inconsiderably. In other sector had increasing capability of sharks fish processing for food and vitaminsextraction [3]. Indonesia had been known as one of the bigest sharks catch country in the world with 103,245 tons in 2011 and 105,230 tons in 2018 . Sharks can be as the main target as well as by catch infishingoperations [4]. As mention by [5] high demand for shark fins and rays for soup, celebratory dish in Asian cuisines and more specifically of the pre-branchial appendages or gill rakers of mobulid rays (Family Mobulidae) is reality. Also the demand for medicinal purposes had drives to uncontrolled exploitation of the vulnerable elasmobranch fishes [6-9]. One of rare demersal shark catch from Java sea is Rhina ancylostoma. The International Union for Conservation of Nature (IUCN) had classified $R$. ancylostoma as in category of vulnerable since it was widely caught by artisanal and commercial fishery especiallyfor its valuable fins. As by-catch of bottom trawlersand tuna long liners it was regardedwill damage the net unit by its thorny skin, but stillcollect the catch forhigh price of its fins only. Habitat degradation and the fishing operations had more challenge to these sharks survival and populationsespescialy at Java Sea. Sharks known as demersal fish and mostly inhabit on the bottom of the sea and thus assumed to have correlation with the depth of the sea as the habitat [10]. Aim of study is to explore morphology and molecular biology ofdemersal $R$. ancylostoma catch from Java Sea landed at Cirebon, Tegal and Rembang fishing port.

\section{METHODOLOGY}

\subsection{Samples and Studysites}

The data ofdemersalshark-rays $R$. ancylostoma were collected from fisherman catch from Java sea landed at Cirebon, Tegal and Rembang fishing port (Fig. 1). Quantitative yearly data of sharks catch was collected from three fishing port at north Java for period of 2011-2018. Shark catch operation by fishermen at Java sea were mostly using bottom gillnet, locally called as 'liong bun' net. Morphology and morphometric measurement involving of the main taxonomical measurements such as Total Length, Standard Length, fin length, distance between dorsal fin-I and II, caudal fin and ventral finand ratios [11].

DNA extraction, amplification and molecular identification of fish specimen. Tissue sampling and collection of fish specimen using scalpel and pinset and sterilized using ethanol 96\% washing with sterilized seawater. Genomic DNA 


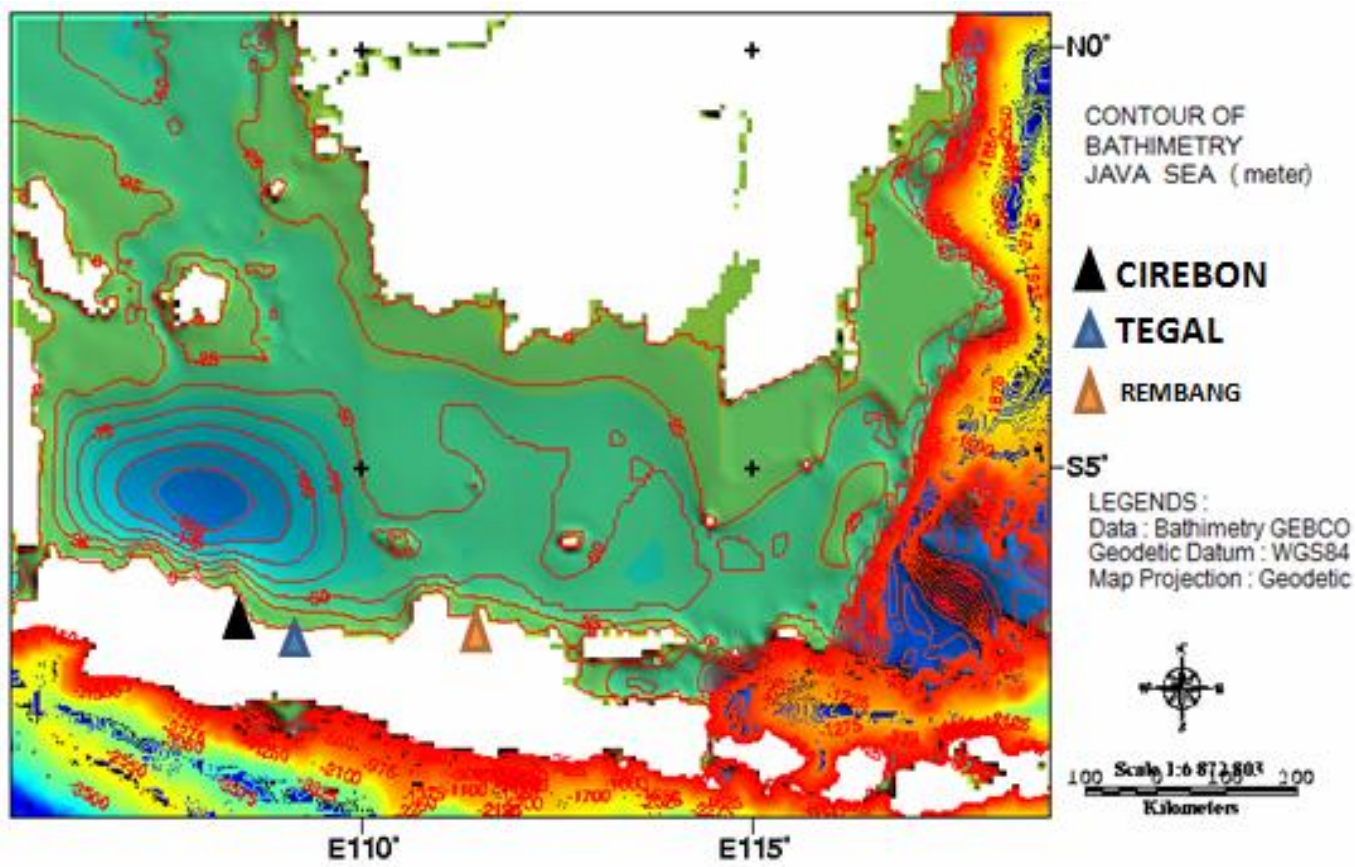

Fig. 1. Bathymetry of Java Sea and fish landing site

extraction using modified Chelex 100 method $[12,13]$. One gram of sample of muscle tissue put in the Eppendorf tubes filled with $500 \mu \mathrm{l}$ of Chelex $10 \%$ solution combined with $7 \mu \mathrm{l}$ proteinase $\mathrm{K}(10 \mathrm{mg} / \mathrm{ml})$. Specimen sample then incubated in heating block at $55^{\circ} \mathrm{C}$ for 90 minute for DNA release, followed with $100^{\circ} \mathrm{C}$ for 20 minute for proteinase- $\mathrm{K}$ deactivation and centrifuge at 9,000 RPM for 15 minute. Yield of DNA supernatant transferred intoeppendeorf tube and stored in $4^{\circ} \mathrm{C}$ for further process. PCR amplification. Part of Mithocondrial DNA COI (Cytochrome Oxidase subunit -I) gen was amplified using Polymerase Chain Reaction (PCR) method.

An amount of $26 \mu \mathrm{l}$ mix solution of $1 \mu \mathrm{l}$ DNA template, $12.5 \mu$ Bioline My Taq ${ }^{\mathrm{TM}}$ HS Red Mix, $1.25 \mu \mathrm{l}$ forward primer $10 \mathrm{mM}, 1.25 \mu \mathrm{l}$ reverse primer $10 \mathrm{mM}$ and $10 \mu \mathrm{l}$ aquabidest. Primer used was Fish BCL: 5'-TCA ACY AAT CAY AAA GAT ATY GGC AC-3' forward and Fish BCH: 5'ACT TCY GGG TGR CCR AAR AAT CA-3' reverse $[13,14]$. The mix then put into Thermal Cycle for PCR process, with pre-denaturation at $95{ }^{\circ} \mathrm{C}$ for 5 minute, followed with 38 cycles of denaturation at $94^{\circ} \mathrm{C}$ for 30 second. Annealing process at $48{ }^{\circ} \mathrm{C}$ for 30 second then extention at $72^{\circ} \mathrm{C}$ for 45 second and final extention at $72^{\circ} \mathrm{C}$ for 5 minutes. Sample of PCR then visualizedto determine the presence DNA band by electrophoresis method using $1 \%$ agarose and gel-rad colouring. PCR specimen with DNA visualization then purified and sequenced at Genetica Science Indonesia company. Examination on result of forward and reverse sequence, sorted and edited using Mega 7.0 software [13,15]. Then matched up with GenBank database at NCBI using Basic Local Alignment Search Tool (BLAST) analysis. Phylogenetic tree was set using NeighborJoining method, Kimura-2 parameter model and 1,000 bootstrap replication. Some sequence from $\mathrm{NCBI}$ Gen Bank were inputted into phylogenetic tree as comparison.

\section{RESULTS AND DISCUSSION}

\subsection{Morphology}

As widely known that teleost group of Gobiidae as the most rich species group with about 2,228 species found in the tropical seas of Iran, Malaysia, Indonesia and Fiji [16]. The species of Rhina ancylostoma group of elasmobranchia Rhinidae inhabit the bottom of up to $200 \mathrm{~m}$ depth, was regarded as one rare and not well documented species and references. Unlike the case of Mediteransea receiving many migratory and climate cycle changes species [17]. The demersal elasmobranch of $R$. ancylostoma in the study was regarded as a semi enclosed 
ecosystem distributed in a shallow Java sea (Fig. 2). Systematic taxonomy Kingdom:Animalia, Phyllum: Chordata, Class: Chondrichthyes, Order: Rajiformes, Family: Rajidae - J. P. Muller and Henle, 1941, Genus: Rhina- Bloch and J.G Schneider, 1801, Species: $R$. ancylostoma.

Shark ray $R$. ancylostoma catch from Java sea is locally known as 'Mimi shark', or other local name at TegalsariTegal fishing port locally called as 'kupu-kupu' orbutterfly. Specimen of $R$. ancylostoma in the study was caugth from the depth range of $40-60 \mathrm{~m}$ at Java sea by fisherman fishing operation. Described by [1], with morphological characters are as follows. The first base dorsal fin positioned in front of ventral fin base, caudal fin as sickle like form. Snout thick and rounded, no skin denticulation on back edge spiracel. Eye circle at middle of head body with three lines of sharp spine thorns at dorsal. Most of the species distributed along west Indo-Pacific to Papua New Nugini and north Australia and south Africa south Africa. Commonly live at bottom of the sea. Vivipareous with dependency of embryo to the egg yolk biologically not much understood. As predator group with main feeding were on crustacean and mollusc [1]. Snout wedge-shape of Rhynchobatus. Snout broadly rounded of Rhina, three cluster lines of sharp thorns and Rhinagrouped in Rhinidae. Rhinobatidae, body less thick and less shark-like; pectoral fins with origins in front of nostrils and with free rear tips posterior to pelvic-fin origins. Dorsal fins smaller, first dorsal fin with origin behind rear tips of pelvic fins. Key to the species of Rhinidae, snout and anterolateral edges of pre-pectoral head broadly rounded, with a deep indentation separating it from pectoral-fin origin on each side, orbits, middorsal line and shoulders with prominent ridges bearing clusters of small, medium-sized and large triangular thorns or spines. The large spines on the midback triangular and erect like saw teeth. The shoulder spines on 2 prominent ridges, spiracular folds absent, pectoral and pelvic fins high and angular. Caudal fin almost lunate with pre-ventral margin nearly as long as dorsal margin. Maximum total length at $270 \mathrm{~cm}$, males adolescent between 157 - $178 \mathrm{~cm}$ and reaching at range $206-220 \mathrm{~cm}$. Wide ranging of batoid in the tropical Indo-West Pacific. Mostly bottom dweller in coastal areas and inshore coral reefs. Feeding on bottom crustaceans including crab and mollusc. Caught by line gear or nets including shrimp trawls and marketed fresh for consumption. Very sharp spines and spiky, become problem for net gears, difficult to handle and cause damage the whole fish catch. Distributed along the Indo-West Pacific, from Natal coast South Africa, Mozambique, East Africa, Seychelles, Red Sea, Arabia, Oman, the Persian Gulf, India, Sri Lanka, Malaysia, Indonesia (Borneo), Philippines, New Guinea, Thailand, Viet Nam, China, Taiwan Province of China, Korea, Japan, Australia from Western Australia to Northern Territory, Queensland and New South Wales [18,19]. Order RHINOBATIFORMES. Family: RHINIDAE or Rhynchobatidae. Taxonomic characters of large shark-like batoids, adults from $71 \mathrm{~cm}$ to over $3 \mathrm{~m}$ total length, with long stout tails and small pectoral discs. Tiny dermal denticles or placoid scales covering the body. Enlarged denticles or thorns present on dorsal surface on snout, orbits, dorsal and midline of trunk and tail. Body slightly flattened and shark-like and thick trunk. Precaudal tail moderately depressed, with lateral ridges on sides, tail not abruptly narrower than trunk, no barbed sting or stinging spine on dorsal surface of tail behind dorsal fins. Head narrow to broad and moderately depressed and snout short to moderately elongated, bluntly rounded or angular. Snout supported by a stout rostral cartilage and not formed into a rostral saw and without lateral saw teeth. Five small gill openings on underside of front half of pectoral-fin bases, not visible in lateral view, no gill sieves or rakers on internal gill slits. Eyes dorsolateral on head and just anterior to spiracles. Mouth more or less arched and with prominent knobs and depressions. Nostrils anterior to mouth and separated from it by less than their own widths. Always separate from each other and mouth; anterior nasal flaps short, not connected with each other and not reaching mouth. Oral teeth small to moderately large, rounded-oval in shape and without cusps on their crowns, not laterally expanded and plate-like, similar in shape and in 32 to 76 rows in either jaw. Pectoral fins small, originating in front of mouth but behind nostrils, attached to post-rostral head and ending anterior to pelvic-fin origins. No electric organs at bases of pectoral fins. Pelvic fins angular, not divided into anterior and posterior lobes. Two large subequal and widely separated dorsal fins present, these of similar falcate shark-like shape with distinct apices, anterior, posterior and inner margins and free rear tips. First dorsal fin originates over anterior half of total length, origin anterior to rear tips of pelvic fins and junction between trunk and tail. Caudal fin large, sharklike and asymmetrical, with vertebral axis raised above body axis, lower caudal-fin lobe present and large. Color of dorsal surface yellowish, 
brownish, grey-brown, or greenish, white below.Dorsal surface with small to large white spots and sometimes dark blotches and dark ocelli on pectoral fins [18-20].

\subsection{Morphometry}

Morphometric measurement on the specimen collected from the fish auction hall of north Java coast have Total Length (TL): $162 \mathrm{~cm}$, Standard Length (SL): $128 \mathrm{~cm}$, wide of ventral fin: $66 \mathrm{~cm}$ and weight: $65 \mathrm{~kg}$ (Fig. 2). As comparison this shark TL canreach upto $270 \mathrm{~cm}$ at Cilacap fishing porth south Java fishing port from the Indian ocean fishing operation.Complete morphometric measurements as presented in Table 1. Based on ratio of Body Width to Standard Length (SL): 0.77 was almost near to 1.0 meaning that Body depth to $S L$ ratio has describe the specimen as a wide body and a depressed head type of fish.Based on shark catch data collected from Cirebon, Tegal and Rembang fishing port revealed that Total Length (TL) of $R$. ancylostoma in range of $76-200 \mathrm{~cm}$, with most dominant TL wasin the class category of101 - $125 \mathrm{~cm}$ (Fig. 3). Mature male wasfound in the TL of $157-178 \mathrm{~cm}$. Dominant TL was found in the range of $120 \mathrm{~cm}$ and least dominant TL was in the range of $76-100 \mathrm{~cm}$ and $151-175$ $\mathrm{cm}[3,21]$.

Fundamentally, two pattern of sharks spatial distribution at Java sea, that isaround west Java sea during west season but spread along west to east of Java sea during east season. Based on assumption that these sharks are bottom living species, thenbathymetric or depth related distribution analysisonshark catch of Rhina ancylostoma, Rhynchobatusdjiddensis (Junjunan shark) and Rhinobatosschegelii (Depo shark) was spatially distributed due to their ecological suitable depth. Sharks catch along Java sea was exclusively dominated by $R$. schlegelii and $R$. djiddensis. Highest monthly catch of $R$. djiddensis during west season (rainy season) was $7,440 \mathrm{~kg}$ and highest monthly catch 7,383 $\mathrm{kg}$ of $R$. schlegelii during east season (dry season). Catch of the three main sharks $R$. ancylostoma, $R$. djiddensis and $R$. schegelii (OrdoRajiformes) at Java sea was distributed in the depth range of $11-167 \mathrm{~m}$ during east season. Specific highest catch was foundat 167 $\mathrm{m}$ depth for $R$. schegelii and theeast season catch was higher than west season. Depth distribution during west season at the depth range of $14-134 \mathrm{~m}$ and specifically around 47 $\mathrm{m}$ depth for $R$. djiddensis. Much lower catch during west season because of heavy rain and high waves in the sea. Also noted that $R$. djiddensis catch wasalways found in every depth range [22]. The study also revealed that depth and sea bottom substrate which are mostly siltclay had related to the sharks spatial distribution. Which is further to form as ecological-cluster for mostofdemersal fish such as sharks spatial distribution [23,24]. Monthly averages of sharks catch year 2018 atnorth Java sea highest catch in May was 20,617 kg and lowest catch in January with $2,122 \mathrm{~kg}$ and average yearly total catch of $72,480 \mathrm{Kg}$ the catch of north Java sea is 26,08 percent compared to shark catch of south Java (Indian ocean) average yearly catch 2018 Cilacap fishing port south Java sea $1,877,844 \mathrm{~kg}$ with highest catch in September with $331,928 \mathrm{~kg}$ and lowest catch in November with 69,630 kg. About 16 family and 38 species of sharks catch had been recorded (Table 2). The most dominant of shark catch from Java sea was Alopiassuperciliosuswith $33.43 \%$, the smallest catch was Sphyrnazygaena with $0.01 \%$ while $R$. ancylostoma with $0.54 \%$ of the total yearly catch data [21].

DNA Amplification. Result on DNA amplifica-tion of isolate sample $\mathrm{AH} 2$ had exhibit of a single band with size of 700 base pair (bp) according to the comparison of DNA marker of the DNA electrophoresis and DNA sequencing as in Fig. 4. Band size was corresponding with fish DNA gene that commonly 700 length bases pair (Pringgenis and Susilowati, 2016). Analysis of Molecular Philogenetic. Based on DNA sequencing as in Figs. 4 and 5, then result was followed with molecularphylogenetic analysis of sample $\mathrm{AH} 2$ based on neighbor joining method with 1000x bootstrap as presented in Fig. 6 .

Result on sequencing of isolate $\mathrm{AH} 2$ sample, followed with further search in the DNA database GenBank using BLAST system on the [25] National Center for Biotechnology Information, National Institute for Health, USA (http://www.ncbi.nlm.nih.gov). Result search of $\mathrm{AH} 2$ isolate hadconfirmed homology on $100 \%$ gene 700 bp as mitochondria DNA Co1 and identified as Rhina ancylostoma with reference Access Number KU721838.1 (Table 1). Result of sequencing on sample $\mathrm{AH} 2$ as species of Rhina ancylostoma with Accession No LC505461 as in Tabel 2. The nearest genetic distance of sampple $\mathrm{AH} 2$ to Rhina ancylostoma 0.02 and thus include withfamily of Rhynchobatushorkelii of 0.017 and $R$. australiae, while the longest distance to Potamotrygon motoro is 0.243 (Fig. 6 and Tables 3,4 and 5. 


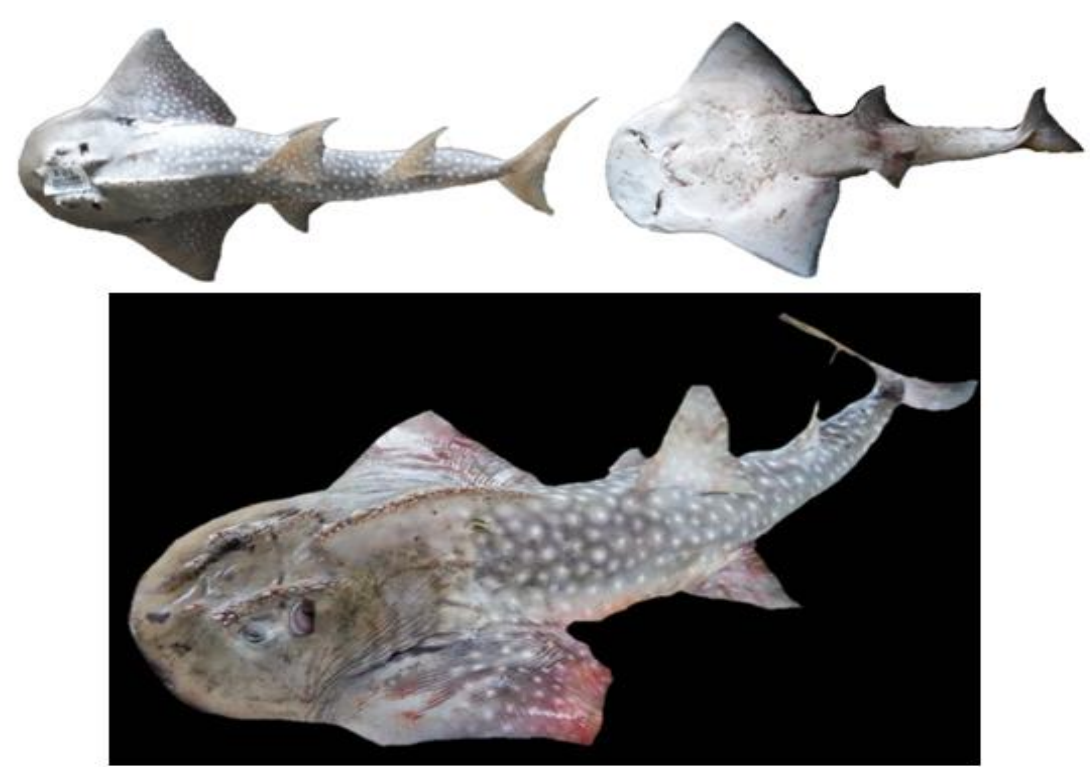

Fig. 2. Morphology (Dorsal and ventral) of specimen AH2 - Rhina ancylostoma

Table 1. Morphometric measurement of $\boldsymbol{R}$. ancylostoma

\begin{tabular}{llll}
\hline Characters & $\%$ & Characters & $\%$ \\
\hline Standard length $(\mathrm{cm})$ & 128 & Head length $(\mathrm{cm})$ & 22 \\
Body depth/SL & $32 / 128(0.25)$ & Body depth/HL & $32 / 22(1.45)$ \\
Body width/SL & $98 / 128(0.77)$ & Body width/HL & $98 / 22(4.45)$ \\
Head length/SL & $22 / 128(0.172)$ & Head length/HL & $22 / 22(1.0)$ \\
Snout length/SL & $16 / 128(0.125)$ & Snout length/HL & $16 / 22(0.73)$ \\
Eye diameter/SL & $4.5 / 128(0.035)$ & Eye diameter/HL & $4.5 / 22(0.205)$ \\
Predorsal length/SL & $56.5 / 128(0.441)$ & Predorsal length/HL & $56.5 / 22(2.57)$ \\
Prepelvic length/SL & $76.5 / 128(0.597)$ & Prepelvic length/HL & $76.5 / 22(3.48)$ \\
First dorsal base length/SL & $12 / 128(0.094)$ & First dorsal base length /HL & $12 / 22(0.55)$ \\
Second dorsal fin base & $9.5 / 128(0.074)$ & Second dorsal fin base & $9.5 / 22(0.43)$ \\
length/SL & & length/HL & \\
Anal base length /SL & $52 / 128(0.406)$ & Anal fin base length $/ \mathrm{HL}$ & $52 / 22(2.36)$ \\
Caudal fin length /SL & $8 / 128(0.063)$ & Caudal fin length $/ \mathrm{HL}$ & $8 / 22(0.36)$ \\
Pectoral fin length /SL & $12.5 / 128(0.098)$ & Pectoral fin length $/ \mathrm{HL}$ & $12.5 / 22(0.57)$ \\
\hline
\end{tabular}



Fig. 3. Total length (TL, $\mathrm{cm}$ ) variation $R$. ancylostoma catch from Java Sea 
Table 2. Scpecies of sharks catch from Java Sea 2011-2018

\begin{tabular}{|c|c|c|c|c|}
\hline Ordo & Family & No. & Species & Common name \\
\hline Squaliformes & Squalidae & 1. & Squalus sp. & Indonesian GreeneyeSpurdog \\
\hline Squatiniformes & Squatinidae & 2. & Squatina sp. & Indonesian Angelshark \\
\hline \multirow[t]{5}{*}{ Orectolobiformes } & Hemiscyllidae & 3. & Chiloscyllium indicum & Slender Bambooshark \\
\hline & & 4. & Chiloscyllium plagiosum & WhitespottedBambooshark \\
\hline & & 5. & Chiloscyllium punctatum & BrownbandedBambooshark \\
\hline & Rhincodontidae & 6. & Rhincodon typus & Whale Shark \\
\hline & Stegostomatidae & 7. & Stegostoma fasciatum & Zebra Shark \\
\hline \multirow[t]{6}{*}{ Lamniformes } & Alopiidae & 8. & Alopias pelagicus & Pelagic Thresher \\
\hline & & 9. & Alopias superciliosus & Bigeye Thresher \\
\hline & Lamnidae & 10. & Isurus oxyrinchus & ShortfinMako \\
\hline & & 11. & Isurus paucus & LongfinMako \\
\hline & Odontaspididae & 12. & Odontaspis ferox & Sandtiger Shark \\
\hline & Pseudocarchariidae & 13. & Pseudocarcharias kamoharai & Crocodile Shark \\
\hline \multirow[t]{19}{*}{ Carcharhiniformes } & Carcharhinidae & 14. & Carcharhinus brevipinna & Spinner Shark \\
\hline & & 15. & Carcharhinus dussumieri & Whitecheek Shark \\
\hline & & 16. & Carcharhinus falciformis & Silky Shark \\
\hline & & 17. & Cacharhinus limbatus & Common Blacktip Shark \\
\hline & & 18. & Carcharhinus macloti & Hardnose Shark \\
\hline & & 19. & Carcharhinus plumbeus & Sandbar Shark \\
\hline & & 20. & Carcharhinus sealei & Blackspot Shark \\
\hline & & 21. & Carcharhinus sorrah & Spot-tail Shark \\
\hline & & 22. & Galeocerdo cuvier & Tiger shark \\
\hline & & 23. & Lamiopsis temmincki & Broadfin Shark \\
\hline & & 24. & Loxodon macrorhinus & Sliteye Shark \\
\hline & & 25. & Prionace glauca & Blue Shark \\
\hline & & 26. & Rhizoprionodon oligolinx & Grey Sharpnose Shark \\
\hline & Hemigaleidae & 27. & Chaenogaleus macrostoma & Hooktooth Shark \\
\hline & & 28. & Hemigaleus microstoma & Sicklefin Weasel Shark \\
\hline & & 29. & Hemipristis elongata & Fossil Shark \\
\hline & Scyliorhinidae & 30. & Atelomycterus marmoratus & Coral Catshark \\
\hline & Sphyrnidae & 31. & Sphyrna lewini & Scalloped Hammerhead \\
\hline & & 32. & Sphyrna mokarran & Great Hammerhead \\
\hline
\end{tabular}


Hartoko et al.; ARRB, 35(4): 19-31, 2020; Article no.ARRB. 57207

\begin{tabular}{|c|c|c|c|c|}
\hline Ordo & Family & No. & Species & Common name \\
\hline & & 33. & Sphyrna zygaena & Smooth Hammerhead \\
\hline & Triakidae & 34. & Mustelus of manazo & Sparse-spotted Smoothhound \\
\hline \multirow[t]{4}{*}{ Rhinobatiformes } & Rhinidae & 35. & Rhina ancylostoma & Shark Ray \\
\hline & Rhinobatidae & 36. & Rhinobatos thouin & Clubnose Guitarfish \\
\hline & & 37. & Rhinobatos typus & Giant Shovelnose Ray \\
\hline & Rhynchobatidae & 38. & Rhynchobatus australie & Whitespotted Guitarfish \\
\hline
\end{tabular}




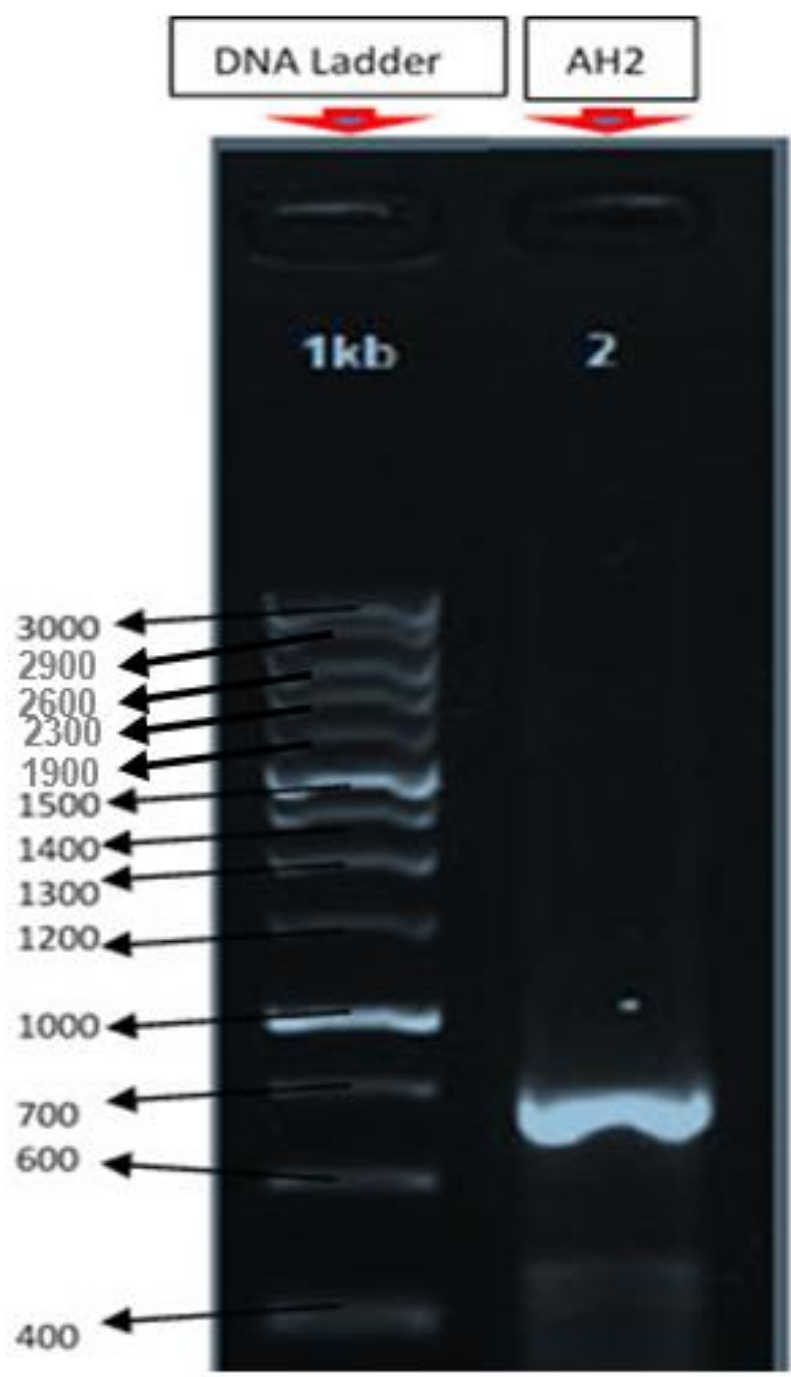

Fig. 4. DNA electrophoresis of AH2 sample

GGCACCTTATATTTGATCTTTGGTGCTTGAGCAGGAATAGTTGGTACTGGTCTAAGTT TACTTATTCGAACAGAGCTTAGCCAACCCGGAACACTTCTTGGAGATGACCAAATCTA TAATGTAGTTGTAACAGCCCATGCCTTCGTAATGATTTTCTTCATAGTCATGCCAATC ATAATTGGAGGGTTTGGTAATTGATTAATTCCTTTAATAATTGGCGCCCCAGACATAG CATTCCCACGAATAAATAATATAAGCTTCTGATTGTTACCTCCATCATTCCTTCTTTTA TTAGCCTCTGCTGGAGTTGAAGCTGGAGTCGGAACAGGTTGAACTGTATACCCCCCA CTTGCTGGTAACCTCGCCCATGCTGGAGCCTCCGTAGACTTAGCCATTTTTTCATTAC ATTTAGCCGGGGTATCCTCTATCCTAGCATCCATTAATTTTATTACAACAATCATTAAC ATAAAACCCCCAGCAATCTCTCAGTATCAGACACCTTTATTTGTGTGGTCAATTCTTG TAACAACCGTTCTTCTACTACTCTCATTACCTGTACTAGCAGCGGGTATTACCATACT CCTCACAGATCGAAATCTTAATACTACTTTCTTTGACCCAGCAGGAGGCGGAGATCC AATCCTTTATCAACATTTATTCTGATT

Fig. 5. Result on DNA sequencing of sample AH2 


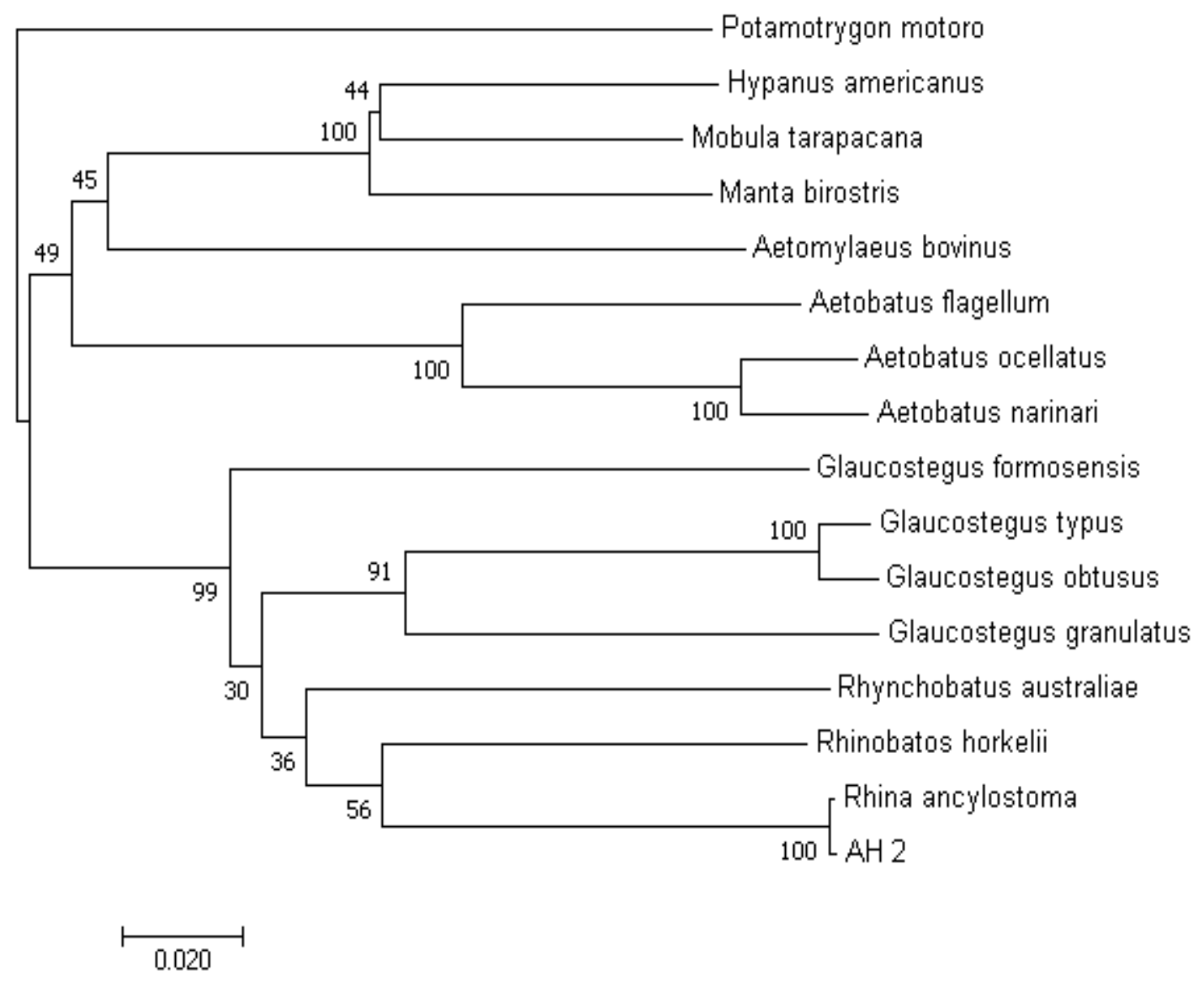

Fig. 6. Philogenetic tree of sample DNA (AH2) confirmed species Rhina ancylostoma

Table 3. Homological match up result of sequence with Gen Bank database

\begin{tabular}{lllllll}
\hline No. & $\begin{array}{l}\text { Original } \\
\text { code }\end{array}$ & $\begin{array}{l}\text { Species Identification } \\
\text { (BLAST) }\end{array}$ & $\begin{array}{l}\text { Access } \\
\text { number }\end{array}$ & $\begin{array}{l}\text { Length } \\
\text { sequence (bp) }\end{array}$ & $\begin{array}{l}\text { Ident } \\
\text { similarity (\%) }\end{array}$ & $\begin{array}{l}\text { Query } \\
\text { cover (\%) }\end{array}$ \\
\hline 1. & AH2 & Rhina ancylostoma & KU721837.1 & 665 & $99,84 \%$ & $100 \%$ \\
\hline
\end{tabular}

Table 4. Sample accession number

\begin{tabular}{llll}
\hline No. & Original code & Species & Accession number \\
\hline 1. & $\mathrm{AH} 2$ & Rhina ancylostoma & LC505461 \\
\hline
\end{tabular}

The series of combination in line to species characterisation has been developed. Started with morphological character with its very distinctive three lines of spine thorn on the head. Morphometry wascharacterised with ratio of width of head to Standard Length (SL) is 0.77 as wide depreseed head fish. The use of the right DNA solvent and fish primer lead to the category of the right for fish molecular weight of the DNA marker [26]. The result of DNA based on phylogenetic tree had confirmedthe nearest genetic distance of 0.02 to Rhincobatushorkelii and 0.017 to $R$. australiae. Longest genetic distance of 0.243 to Potamotrygon motoro. In comparison to reality on diversity of shark catch from Java sea are Rhinobatos thouin, Rhinobatos typus related grorup in the family, where Rhincobatushorkeli iwas not found in the catch from Java sea. 
Hartoko et al.; ARRB, 35(4): 19-31, 2020; Article no.ARRB.57207

Table 5. Genetic distance of sample AH2 to other species

\begin{tabular}{|c|c|c|c|c|c|c|c|c|c|c|c|c|c|c|c|c|}
\hline & 1 & 2 & 3 & 4 & 5 & 6 & 7 & 8 & 9 & 10 & 11 & 12 & 13 & 14 & 15 & 16 \\
\hline $\begin{array}{l}\text { 1.Potamotrygon } \\
\text { motoro }\end{array}$ & & 0.214 & 0.221 & 0.258 & 0.252 & 0.245 & 0.237 & 0.267 & 0.267 & 0.261 & 0.243 & 0.234 & 0.249 & 0.255 & 0.261 & 0.243 \\
\hline $\begin{array}{l}\text { 2.Hypanus } \\
\text { americanus }\end{array}$ & 0.021 & & 0.107 & 0.235 & 0.243 & 0.259 & 0.117 & 0.272 & 0.277 & 0.245 & 0.264 & 0.209 & 0.251 & 0.246 & 0.222 & 0.262 \\
\hline $\begin{array}{l}\text { 3.Mobula } \\
\text { tarapacana }\end{array}$ & 0.022 & 0.013 & & 0.227 & 0.251 & 0.230 & 0.107 & 0.261 & 0.263 & 0.240 & 0.239 & 0.217 & 0.250 & 0.248 & 0.239 & 0.233 \\
\hline $\begin{array}{l}\text { 4. Rhyncobatus } \\
\text { australiae }\end{array}$ & 0.023 & 0.022 & 0.021 & & 0.174 & 0.171 & 0.244 & 0.203 & 0.193 & 0.182 & 0.200 & 0.233 & 0.272 & 0.292 & 0.284 & 0.173 \\
\hline $\begin{array}{l}\text { 5. Rhinobatos } \\
\text { horkelii }\end{array}$ & 0.023 & 0.023 & 0.023 & 0.018 & & 0.147 & 0.230 & 0.195 & 0.197 & 0.211 & 0.164 & 0.253 & 0.283 & 0.277 & 0.267 & 0.145 \\
\hline $\begin{array}{l}\text { 6. Rhina } \\
\text { ancylostoma }\end{array}$ & 0.023 & 0.024 & 0.021 & 0.018 & 0.017 & & 0.249 & 0.201 & 0.203 & 0.199 & 0.218 & 0.227 & 0.280 & 0.293 & 0.274 & 0.002 \\
\hline 7.Manta birostris & 0.023 & 0.015 & 0.014 & 0.022 & 0.022 & 0.023 & & 0.259 & 0.271 & 0.264 & 0.252 & 0.199 & 0.240 & 0.235 & 0.226 & 0.251 \\
\hline $\begin{array}{l}\text { 8.Glaucostegus } \\
\text { typus }\end{array}$ & 0.024 & 0.024 & 0.023 & 0.020 & 0.018 & 0.019 & 0.022 & & 0.018 & 0.151 & 0.197 & 0.275 & 0.261 & 0.257 & 0.244 & 0.199 \\
\hline $\begin{array}{l}\text { 9. Glaucostegus } \\
\text { obtusus }\end{array}$ & 0.024 & 0.025 & 0.023 & 0.020 & 0.018 & 0.020 & 0.023 & 0.005 & & 0.164 & 0.187 & 0.278 & 0.251 & 0.252 & 0.244 & 0.201 \\
\hline $\begin{array}{l}\text { 10.Glaucostegus } \\
\text { granulatus }\end{array}$ & 0.023 & 0.021 & 0.021 & 0.018 & 0.020 & 0.019 & 0.023 & 0.018 & 0.018 & & 0.220 & 0.266 & 0.271 & 0.267 & 0.252 & 0.201 \\
\hline $\begin{array}{l}\text { 11.Glaucostegus } \\
\text { formosensis }\end{array}$ & 0.022 & 0.024 & 0.022 & 0.021 & 0.018 & 0.021 & 0.024 & 0.020 & 0.019 & 0.021 & & 0.279 & 0.259 & 0.259 & 0.254 & 0.216 \\
\hline $\begin{array}{l}\text { 12. Aetomylaeus } \\
\text { bovinus }\end{array}$ & 0.023 & 0.021 & 0.021 & 0.022 & 0.024 & 0.023 & 0.021 & 0.025 & 0.025 & 0.024 & 0.025 & & 0.251 & 0.239 & 0.228 & 0.230 \\
\hline $\begin{array}{l}\text { 13.Aetobatus } \\
\text { ocellatus }\end{array}$ & 0.023 & 0.023 & 0.023 & 0.023 & 0.025 & 0.024 & 0.023 & 0.023 & 0.023 & 0.023 & 0.024 & 0.023 & & 0.041 & 0.116 & 0.283 \\
\hline $\begin{array}{l}\text { 14.Aetobatus } \\
\text { narinari }\end{array}$ & 0.023 & 0.023 & 0.023 & 0.025 & 0.024 & 0.026 & 0.023 & 0.022 & 0.022 & 0.023 & 0.024 & 0.023 & 0.008 & & 0.130 & 0.296 \\
\hline $\begin{array}{l}\text { 15.Aetobatus } \\
\text { flagellum }\end{array}$ & 0.024 & 0.021 & 0.022 & 0.025 & 0.023 & 0.025 & 0.023 & 0.021 & 0.021 & 0.023 & 0.023 & 0.023 & 0.014 & 0.015 & & 0.272 \\
\hline 16.AH-2 & 0.022 & 0.024 & 0.021 & 0.018 & 0.016 & 0.002 & 0.023 & 0.019 & 0.020 & 0.020 & 0.021 & 0.023 & 0.024 & 0.026 & 0.025 & \\
\hline
\end{tabular}




\section{CONCLUSION}

Rhina ancylostoma is one of demersal shark rays catch from Java Sea. Range of Total Length (TL) of catch $73-200 \mathrm{~cm}$ with dominant TL fish catch $125 \mathrm{~cm}$. Morphological character withthree lines of spine thorn on the head, morphometrywith wide head ratio to SL 0.77 as wide depressed head. DNA analysis had confirmed the specimen of $\mathrm{AH} 2$ as Rhina ancylostoma based on homological match up of sequence of GenBank database with reference accesion number KU721837.1 with length sequence of $665 \mathrm{bp}$ identical similarity of $99.84 \%$ for specimen Accession number LC 505461. Nearest genetic distance of 0.02 to Rhincobatushorkelii and 0.017 to $R$. australiae. Longest genetic distance of 0.243 to Potamotrygon motoro.

\section{ETHICAL APPROVAL}

As per international standard written ethical permission has been collected and preserved by the author(s).

\section{ACKNOWLEDGEMENTS}

The authors would like very much to thanks to the Rector of Diponegoro University for the grant No.1023.UN7.P/HK/2019 for Post Doctoral/ Sabatical of World Class University Programme. Diponegoro University.

\section{COMPETING INTERESTS}

Authors have declared that no competing interests exist.

\section{REFERENCES}

1. White WT, Last PR, Stevens JD, Yearsley GK, Fahmi D. Economically important sharks and rays of Indonesia (in Indonesian). Australian Centre for International Agricultural Research. 2006; 338 .

2. Widodo AA, Mahulette RT. Species, size and fishing ground thresher shark (family alopidae) by catch of tuna longline indian ocean. Fisheries Journal of Indonesia. 2012;4(2):75-82.

3. Dian Arifiyani, Muslihuddin Aini SA. No Title. Monitoring on Sharks Catch of Java Sea. Loka Pengelolaan Sumberdaya Pesisir dan Laut.Serang Banten; 2014.

4. MMF. Sharks Production of Java Sea; 2012.

5. Ward-Paige CA, Davis B, Worm B. Global Population Trends and Human Use
Patterns of Manta and Mobula Rays. PLoS ONE. 2013;8(9):e74835.

6. Dirk Steinke, Andrea M. Bernard, Rebekah L. Horn, Paul Hilton, Robert Hanner MSS. DNA analysis of traded shark fins and mobulid gill plates reveals a high proportion of species of conservation concern. 2006;7:9505 (9505):9505.

Available:Www.Nature.Com

7. Clarke SC, et al. Global estimates of shark catches using trade records from commercial markets. Ecology Letters. 2006;9(10):1115-1126.

8. Croll DA, Dewar H, Dulvy NK, Fernando D, Francis MP, Galván-Magaña $F$, Hall $M$, Heinrichs S, Marshall A, Mccauley D, Newton KM, Notarbartolo-Di-Sciara G, O'Malley M, O'Sullivan J, Poortvliet M, Roman M, Stevens G, Tershy BR, White, WT. Vulnerabilities and fisheries impacts: the uncertain future of manta and devil rays. Aquatic Conservation: Marine and Freshwater Ecosystems. 2016;26(3):562575.

Available:https://doi.org/10.1002/aqc.2591

9. Zeng $\mathrm{Y}$, et al. DNA barcoding of mobulid ray gill rakers for implementing CITES on elasmobranch in China. Scientific Reports. 2016;6(6).

10. Hartoko A. Oceanography and fisheries resources of Indonesia. Undip press. ISBN; 2010.

11. Dharmadi Benaya Simeon EM. Identification Training on Sharks and Rays. MMF-Coral Triangle Inisiative-WCS; 2019.

12. Walsh PS, Metzger DA HR. Chelex 100 as a medium for simple extraction of DNA for PCR-based typing from forensic material. Biotechniques. 1991;10(4):506-513.

13. Alghozali FA, Wijayanti DP, Sabdono A. Short communication: Genetic diversity of scalloped hammerhead sharks (Sphyrna lewini) landed in muncar fishing port, Banyuwangi. Biodiversitas; 2019.

Available:https://doi.org/10.13057/biodiv/d 200430

14. Baldwin CC, Mounts JH, Smith DG, Weigt, LA. Genetic identification and color descriptions of early life-history stages of Belizean Phaeoptyx and Astrapogon (Teleostei: Apogonidae) with comments on identification of adult Phaeoptyx. Zootaxa, 2009;22(2008):1-22.

Available:https://doi.org/10.5281/zenodo.1 85750 
15. Tamura K, Dudley J, Nei M, Kumar S. MEGA4: Molecular Evolutionary Genetics Analysis (MEGA) software version 4.0. Molecular Biology and Evolution. 2007;24 (8):1596-1599.

Available:https://doi.org/10.1093/molbev/m sm092

16. Sadeghi R, Esmaeili HR. First documentation of an uncommon goby genus and species, Palutrus scapulopunctatus (de Beaufort, 1912) from the Persian Gulf (Teleostei: Gobiidae). Iranian Journal of Ichthyology. 2019;6(3): 143-149.

Available:https://doi.org/10.22034/iji.v6i3.4 46

17. Alshawy F, Ibrahim A, Hussein C, Lahlah $M$. First record of the spotfin cardinal fish jaydia queketti (Gilchrist, 1903) (Teleostei: Apogonidae) from the Syrian marine waters (eastern mediterranean). Iranian Journal of Ichthyology. 2019;6(2):138-142. Available:https://doi.org/10.22034/iji.v6i2.4 06

18. Compagno LVJ, Last PR. FAO species identification guide for fishery purposes. The living marine resources of the Western Central Pacific. Batoid fishes, chimaeras and bony fishes part 1 (Elopidae to Linophrynidae) (K. E. C. and V. H. N. (eds). 1999;3.

19. Compagno LJV, Ishihara H. Rhinobatos schlegelii. In: IUCN 2013. IUCN Red List of Threatened Species. Version; 2013. Available:www.iucnredlist.org

20. Notarbartolo di Sciara G, Bradai MN, Morey G, Marshall AD, Compagno LJV,
Mouni A, Hicham M, Bucal D, Dulvy NAH. Coelho R. Rhinobatos rhinobatos. The IUCN Red List of Threatened Species, e.T63131A1.

21. MMF; Shark Production of North and South Java. Ministry of Marine and Fisheries; 2007.

22. Dudley SFJ, Cavanagh RD. Rhynchobatus djiddensis. The IUCN Red List of Threatened Species. 2015;8235.

23. Hartoko A, Wibowo P. Multi layer spatial analysis for demersal shrimp fishery and Sst Warming in the Semarang Coastal Waters. Journal of Coastal Development. 2011;15(1):17-23.

24. Hartoko A, Febrianto A, Pamungkas A, Fachruddin I, Helmi M, Hariyadi. The myth and legend of Sadai and Gaspar strait Bangka Belitung (BancaBilliton) and oceanographic conditions. International Journal of GEOMATE. 2019;17(62):212-218.

Available:https://doi.org/10.21660/2019.62. 93965

25. NCBI. National Center for Biotechnology Information, National Institute for Health, USA; 2019.

Available:http://www.ncbi.nlm.nih.gov

26. Pringgenies $D$, Susilowati R. Highly commercial fisheries tawar fish: Molecular analysis dna mitochondrial coi gene sequence and proximate analysis from malacca strait, Riau. Jurnal Teknologi. 2016;78(4-2):33-38.

Available:https://doi.org/10.11113/jt.v78.81 49

(c) 2020 Hartoko et al.; This is an Open Access article distributed under the terms of the Creative Commons Attribution License (http://creativecommons.org/licenses/by/4.0), which permits unrestricted use, distribution, and reproduction in any medium, provided the original work is properly cited.

Peer-review history:

The peer review history for this paper can be accessed here: http://www.sdiarticle4.com/review-history/57207 